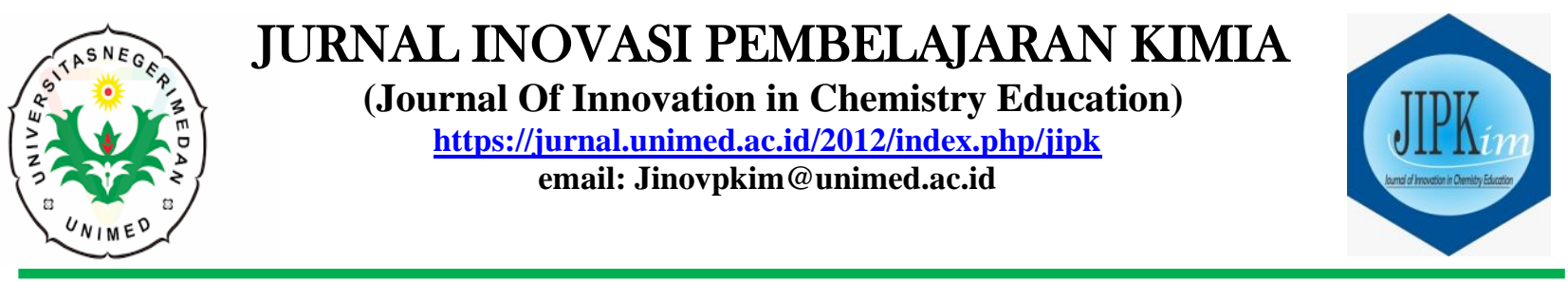

\title{
PENGEMBANGAN MODUL LAJU REAKSI BERBASIS PEDAGOGICAL CONTENT KNOWLEDGE (PCK) UNTUK MENINGKATKAN HASIL BELAJAR SISWA
}

\author{
Frisca Zahrona Utami Harahapa,*, Destria Roza ${ }^{a}$ \\ ${ }^{a}$ Program Studi Pendidikan Kimia, Universitas Negeri Medan, Medan \\ *Alamat Korespondensi: friscazahrona98@gmail.com
}

\begin{abstract}
:
This study aims to analyze the feasibility of the PCK Chemistry module and learning outcomes on the subject matter of the reaction rate taught by the PCK Chemistry module class XI MAN 1 Medan Medan. The selected sample is class XI MIA 3 as an experimental class. The method used in this research is $R \& D$. The module analysis results state that the average overall validation result is 3.65 which means that the module is feasible to use. While the results of the module analysis based on the respondents obtained an average of 3.70 which means that the developed PCK module is appropriate to use. This is also evidenced from student learning outcomes that are taught using the PCK chemistry module. Hypothesis testing is done by using the t-one party test that is the right side, with the results of this study at a significance level of $5 \%(\alpha=0.05)$ indicating that tcount $>$ t table $(12.63>1.68)$ then Ho is rejected. Thus, showing chemistry learning outcomes using the PCK chemistry module is greater or equal to KKM, where an average pretest of 28.25 is obtained and an average of posttest is obtained an average of 86.04 .
\end{abstract}

Keywords:

Modules, Pedagogical Content Knowledge, Reaction Rate, Learning Outcomes

\section{PENDAHULUAN}

Salah satu penentu mutu pendidikan nasional adalah kualitas seorang guru. Hal ini dipaparkan untuk menunjukkan betapa peran guru bisa sangat menentukan kualitas pembelajaran. Menurut Shulman (1986), tiga dimensi pengetahuan professional yang penting bagi guru yaitu salah satunya adalah PCK (Pedagogical Content Knowledge). Dalam hal ini Shulman mengatakan PCK merupakan pengetahuan tentang materi yang diajarkan dan cara mengajarkannya (pedagogi). PCK meliputi asepek-aspek yang berhubungan serta dengan kegiatan mengajar para guru meliputi: aspek-aspek itu adalah ide, analisis, ilustrasi, contoh-contoh, demonstrasi, dan perumusan pokok materi.
Berdasarkan hasil wawancara terhadap siswa di MAN 1 Medan, mereka masih kesulitan dalam memahami pelajaran kimia, dikarenakan guru yang terlalu fokus dalam menjelaskan dan tidak menyadari bahwa siswa-siswa kurang memahami penjelasan guru tersebut, sehingga menyebabkan siswa pasif selama proses pembelajaran. Senada dengan itu, Ristiyanti \& Bahriah (2016), memeroleh indikator aspek guru memengaruhi kesulitan belajar siswa sebesar 77,17\%. Hal ini menunujukkan persentase dengan kriteria tinggi.

Driel (2010), mengungkapkan bahwa dalam pengembangan PCK guru, diperlukan 3 faktor yaitu masukan luar (buku dan sumber lainnya), interaksi dengan rekan 
sesama guru, dan menambah pengalaman mengajar untuk bereksperimen tentang cara mengajar didalam kelas. Lenhart (2010), mengemukakan semakin baik PCK guru, maka hasil belajar siswa juga bisa semakin membaik. Berdasarkan penelitian ini, buku atau sumber ajar lain sangat berpengaruh dalam pengembangan PCK guru. Salah satu bahan ajar adalah modul. Modul merupakan paket belajar yang berkenaan dengan satu unit bahan pelajaran (Prastowo, 2011). Modul juga merupakan salah satu bahan ajar yang dapat memotivasi siswa untuk belajar secara mandiri maupun kelompok dan dapat membantu siswa dalam menemukan konsep (Andromeda, 2018).

\section{METODE}

Jenis penelitian ini mengikuti tahaptahap Research and Development $(R \& D)$ yang meliputi : (1) pendefenisian (define), (2) perancangan (design), (3) pengembangan (develop), (4) penyebaran (dessiminate), uji coba modul dan standarisasi modul.

Penlitian ini dilaksanakan di MAN 1 Medan Jalan Williem Iskandar No.9B, Medan Sumatera Utara pada semester ganjil pada bulan November-Oktober T.A. 2018/2019.

Dalam penelitian ini digunakan desain pretest-posttest satu kelompok (one group pretest-posttest design). Tabel desain penelitian dapat dilihat dalam Tabel 1.

Tabel 1. Rancangan Penelitian Pengembangan Modul PCK Kimia

\begin{tabular}{cccc}
\hline Kelompok & Pre-test & Perlakuan & Post-test \\
\hline Eksperimen & $\mathrm{T}_{1}$ & $\mathrm{X}$ & $\mathrm{T}_{2}$ \\
\hline Keterangan : & & \\
$\mathrm{X}$ & & \\
$\mathrm{T}_{1} \quad=$ Penggunaan modul PCK Kimia & \\
$\mathrm{T}_{2} \quad=$ Pemberian tes awal (pre-test) &
\end{tabular}

\section{Analisis Hasil Belajar}

Teknik analisis data untuk mengetahui hasil penelitian menggunakan uji normalitas,dan uji hipotesis. Untuk menguji hipotesis apakah kebenarannya dapat diterima atau tidak, yang digunakan adalah uji pihak kanan. Dengan taraf nyata $\alpha=0,05$, rumus uji-t sebagai berikut :

$$
t_{\text {hitung }}=\frac{\left(\bar{x}-\mu_{0}\right)}{\frac{S}{\sqrt{n}}}
$$

(Silitonga, 2013)

\section{Persen Peningkatan Hasil Belajar}

Peningkatan adalah ukuran seberapa besar pengaruh yang dijadikan terhadap objek yang diujikan dalam persentase peningktan.

$$
\text { Gain }=\frac{\text { nilai postest-nilai preteset }}{\text { nilai maksimum-nilai pretest }}(3)
$$

Persentasi peningkatan hasil belajar dihitung dengan rumus: Rata-rata persentasi peningkatan $=$ Rata-rata gain $\times 100 \%$

Dengan kriteria g (gain ternormalisasi) :

$$
\begin{array}{ll}
\mathrm{g}<0,3 & : \text { rendah } \\
0,3 \leq \mathrm{g} \leq 0,7 & : \text { sedang } \\
\mathrm{g}>0,7 & \text { : tinggi }
\end{array}
$$

(Meltzer,2002)

\section{HASIL DAN PEMBAHASAN}

Hasil dari setiap tahapan prosedur pengembangan yang dilakukan adalah:

\section{Tahap Pendefenisian (Define)}

Berdasarakan hasil kegiatan observasi (wawancara) dari analisis kebutuhan, dapat diketahui bahwa guru mengalami kendala dalam mengajarkan kimia yang disebabkan oleh buku yang digunakan sebagian besar didalamnya hanya memuat materi, hal ini juga dibuktikan dari hasil belajar siswa yang diperoleh tidak lebih dari nilai KKM.

Tahap selanjutnya adalah, analisis silabus kurikulum 2013. Hasil dari analisis diperoleh bahwa materi yang digunakan untuk pembuatan modul adalah laju reaksi. Hasil studi pustaka mendapat informasi bahwa PCK pengetahuan tentang materi dan cara mengajarkannya. Sehingga dapat didefenisikan bahwa kebutuhan guru tentang modul yang dimaksud adalah modul berbasis pedagogical content knowledge (PCK).

\section{Tahap Perancangan (Design)}

Tahap pengembangan modul ini diadaptasi dari teknik yang disampaikan oleh Sungkono (2003), dengan cara penulis menggunakan berbagai buku dan sumber informasil lain sebagai dasar dalam menulis modul. Tahap ini dimulai dengan menyusun kerangka modul sebagai pemetaan materi 
pembelajaran yang akan dikemas dalam modul.

Tahap perancangan dilanjutkan dengan menentukan komponen-komponen dalam modul, yaitu judul modul, petunjuk penggunaan modul, topic pembelajaran, langkah pembelajaran, uji kompetensi dan lampiran.

3. Pengembangan (develop)

Tahap pengembangan dilakukan validasi yang melibatkan 2 dosen ahli. Validasi dilakukan untuk memberikan penilaian kelayakan modul yang dikembangkan meliputi kelayakan isi, kelayakan bahasa, kelayakan penyajian dan kelayakan kegrafikan. Untuk penilaian dosen mendapat saran dan perbaikan diantaranya tata cara penulisan, penambahan ide dalam pembuatan core dan papers, perbaikan gambar cover, penambahan glosarium dan konsistensi dalam tabel dan gambar.

4. Penyebaran (disseminate)

Penyebaran modul PCK kepada 43 siswa kelas XI MIA 3 MAN 1 Medan, 1 guru kimia di MAN 1 Medan dan 1 guru kimia di SMA Taman Siswa Medan. Modul PCK ini secara umum dapat membantu dalam penyusunan skenario pembelajaran karena didalamnya memuat PCK Kimia yaitu materi dan cara mengajarkannya berdasarkan komponen core dan papers dari Loughran (2012).

5. Uji Coba Penggunaan Modul

Uji coba penggunaan modul ini menggunakan satu kelas sebagai kelas eksperimen. Data hasil belajar siswa dengan penggunaan bahan ajar modul kimia diperoleh melalui evaluasi akhir (posttest) dengan nilai rata-rata yaitu 86,04.

\section{Standarisasi Kelayakan Modul PCK}

Kimia

Standarisasi dilakukan dengan menggunakan instrument BSNP, sehingga diperoleh hasil penilaian dan saran perbaikan. Kemudian setelah mendapat hasil penialaian, modul yang dikembangkan kembali direvisi sesuai dengan hasil penilaian. Data yang diperoleh berupa daftar check list, dimana validator ahli memberikan tanda $(\sqrt{ })$ pada kolom yang sesuai.
Tabel 2. Hasil Validasi Modul

\begin{tabular}{ll}
\hline Komponen Kelayakan & Rata-rata \\
\hline Isi & 3,75 \\
Bahasa & 3,70 \\
Penyajian & 3,37 \\
Kegrafikan & 3,81 \\
\hline Rata-rata Keseluruhan & $\mathbf{3 , 6 5}$ \\
\hline
\end{tabular}

Dari tabel diatas dapat diketahui bahwa validator memberikan pendapat yang positif terhadap modul PCK yang telah dikembangkan, dan berarti bahan modul berbasis PCK kimia pada materi laju reaksi yang telah dibuat peneliti sudah valid dan layak digunakan.

Responden dalam penelitian ini ialah penilaian modul dilakukan kepada 2 guru kimia, dan 40 siswa yang telah menggunakan modul berbasis PCK kimia pada materi laju reaksi di sekolah tempat penelitian, selanjutnya penilai diminta untuk menilai modul berdasarkan aspek tampilan, penyajian materi, dan aspek manfaat. Data hasil angket penilaian dapat dilihat pada tabel 3 .

Tabel 3. Hasil Angket Penilaian modul PCK Kimia

\begin{tabular}{llll}
\hline Komponen & Rata-rata & \\
\hline Aspek Tampilan & 3,80 & & \\
Aspek Materi & 3,67 & & \\
Aspek Manfaat & 3,64 & \\
\hline Rata-rata Keseluruhan & $\mathbf{3 , 7 0}$ & \\
\hline \multicolumn{1}{r}{ Hasil } & rata-rata & perhitungan dari
\end{tabular}

angket penilaian siswa dan guru terhadap modul adalah 3,70. Sesuai dengan skala kriteria kelayakan modul, angka tersebut berada pada rentang skala 3,26-4,00, yang berarti modul yang dikembangkan valid dan tidak perlu revisi.

Karakteristik dari modul PCK yang dikembangan ini adalah :

1. Penyusunan modul disususn berdasarkan core dan papers dengan memunculkan ide-ide besar yang akan dituangkan dalam modul untuk materi laju reaksi yang akan disampaikan kepada siswa untuk mempermudah pemahaman.

2. Memiliki sturuktur modul yang lengkap antara lain terdiri dari deskripsi singkat (short description), petunjuk penggunaan modul, kompetensi inti dan kompetensi dasar, materi yang dikemas secara menarik, lembar kerja siswa, dan soal-soal latihan dan evaluasi. 
3. Memiliki cakupan pembahasan yang terfokus dan terukur, sesuai dengan tujuan yang ingin dicapai dan mudah dipahami oleh siswa. Modul ini juga dilengkapi dengan fenomenafenomana yang sering terjadi dalam kehidupan sehari-hari.

\section{Peningkatan Hasil Belajar}

Berdasrakan perhitungan, maka diperoleh nilai rata-rata pretest siswa yaitu 28,25 dan nilai rata-rata posttest siswa yaitu 86,04. Dari data perhitungan yang menggunakan Microsoft Excel maka dapat digambarkan hasil perolehan rata-rata nilai pretest dan nilai posttest kelas eksperimen melalui diagram pada gambar dibawah ini.

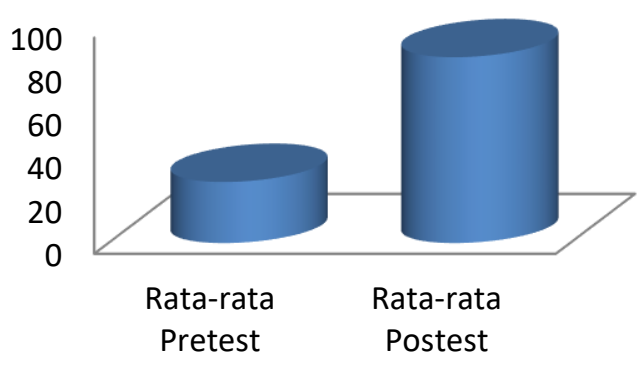

Gambar 1. Rata-rata Hasil Belajar

Perhitungan peningkatan hasil belajar dapat diperoleh dari rata-rata nilai gain seluruh siswa kelas eksperimen dengan dikali $100 \%$. Berdasarkan perhitungan bahwa \% gain kelas eksperimen lebih besar dari 70 sehingga kriteria peningkatan hasil belajar siswa yang menggunakan modul PCK kimia pada materi laju reaksi tergolong tinggi. Maka dapat disimpulkan bahwa penggunaan bahan ajar modul PCK kimia dapat meningkatkan hasil belajar siswa.

\section{PEMBAHASAN}

Berdasarkan hasil uji coba yang dilakukan diperoleh rata-rata tes awal sebesar 28,25 . Selanjutnya diberikan tes akhir. Berdasarkan hasil tes, diperoleh rata-rata tes akhir pada kelas eksperimen sebesar 86,04. Hal ini menunjukkan pada penelitian ini terjadi peningkatan hasil belajar. Selain itu, dilihat dari Kriteria Ketuntasan Minimum (KKM), hasil tes juga berhasil melebihi dari 75. Dengan demikian, menyatakan bahwa hasil belajar kimia menggunakan modul PCK kimia pada materi laju rekasi lebih besar dari nilai KKM.

Berdasarkan data n-gain terdapat peningkatan hasil belajar, yaitu secara keseluruhan 0,80 atau $80 \%$ yang tergolong dalam kategori tinggi. Hal ini membuktikan bahwa pembelajaran dengan menggunakan modul yang dikembangkan pada topik laju reaksi berpengaruh untuk meningkatkan hasil belajar siswa di MAN 1 Medan kelas XI MIA 3. Sesuai dengan penelitian yang dilakukan oleh Adawiyah dkk., (2019), dengan judul penelitian Pengembangan Modul Laju Reaksi Berbasis Konstruktivisme Lima Fase Needham diperoleh rata-rata skor Gain yang diperoleh dari pretest dan posttest sebesar 0,80 (tinggi) dengan kriteria modul yang dikembangkan memenuhi kriteria valid dan dapat digunakan sebagai bahan ajar.

\section{KESIMPULAN}

Modul ini dibuat berdasarkan core dan papers, dengan memunculkan ide-ide besar yang akan dituangkan dalam modul laju reaksi untuk mempermudah pemahaman, memiliki sturuktur modul yang lengkap antara lain terdiri dari deskripsi singkat (short description), petunjuk penggunaan modul, kompetensi inti dan kompetensi dasar, materi yang dikemas secara menarik, lembar kerja siswa, dan soal-soal latihan dan evaluasi, memiliki cakupan pembahasan yang terfokus dan terukur, sesuai dengan tujuan yang ingin dicapai dan mudah dipahami oleh siswa. Modul ini juga dilengkapi dengan fenomena-fenomana yang sering terjadi dalam kehidupan sehari-hari.

\section{DAFTAR PUSTAKA}

Adawiyah, R., Sukaryawan, M., \& Mujamil, J., (2019). Pengembangan

Modul Laju Reaksi Berbasis

Kontruktivisme Lima Fase

Needham, Jurnal Penelitian

Pendidikan Kimia Universitas

Sriwijaya, 6(1):18-24.

Andromeda, E. B., (2018). Validitas dan

Praktikalitas Modul Laju Reaksi 
Tetintegrasi Eksperimen dan Keterampilan Proses Sains untuk Pembelajaran Kimia di SMA, Jurnal Eksakta Pendidikan, 2(2):132-139.

Badan Standar Nasional Pendidikan, (2008). Instrumen Penilaian Buku Teks Pelajaran Pendidikan Dasar Menengah, Depdiknas. Jakarta

Driel, J., (2010). Model-based development of science teachers' Pedagogical Content Knowledge. International Seminar, Proffesional Rreflections, National Science Learning Centre, York.

Lenhart, S., (2010). The Effect Of Teacher Pedagogical Content Knowledge and The Instruction of Middle School Geometry, Liberty Univesity. Disertaion Doctor of Education, Facukty of the School of Education.

Loughran, J., (2012). Science Teachers 'Views on CoRes and PaP-eRs as a Framework for Articulating and Developing Pedagogical Content Knowledge, Resecarch an Science Education, 42:1027-1047 DOI 10.1007/s1165-011-9227-4.

Meltzer, D. E., (2002). The Relationship Between Mathematics Preparation and Conceptual Learning Gains in Physics:A Possible "Hidden Variable" in Diagnostic Pretest Score, American Association of Physics Teachers, 70(12):1259-1268.

Prastowo, A., (2011). Panduan Kreatif Membuat Bahan Ajar Inovatif, Yogyakarta. Diva Press.

Ristiyanti, E., \& Bahriah, E. S., (2016). Analisis Kesulitan Belajar Kimia Siswa di SMAN X Kota Tangerang Selatan, Jurnal Penelitian dan Pembelajaran IPA, 2(1):18-29.

Shulman, L. S., (1986). Those Who Understand: Konwledge Growth In Teaching, Educational Research, 15(2):4-31.

Silitonga, P. M., (2013). Statistika Teori Dan Aplikasi Dalam Penelitian. Universitas Negeri Medan. FMIPA.
Sungkono., (2003). Pengembangan Bahan Ajar, Yogyakarta. FIP UNY. 